JURNAL RISET MAHASISWA AKUNTANSI (JRMA)

Volume 8, No. 1, Tahun 2020

e-ISSN : 2715 - 7016

\title{
PENGARUH PENDAPATAN ASLI DESA (PAD), DANA DESA (DD), ALOKASI DANA DESA (ADD) TERHADAP BELANJA DESA BIDANG PENDIDIKAN DENGAN JUMLAH PENDUDUK MISKIN SEBAGAI VARIABEL MODERASI
}

\author{
Sitiana Muslikah \\ e-mail: siti32124@gmail.com \\ Sulistyo \\ Rita Indah Mustikowati \\ Program Studi Akuntansi, Fakultas Ekonomika dan Bisnis Universitas Kanjuruhan Malang
}

\begin{abstract}
ABSTRAK
Penelitian yang dilakukan oleh peneliti memiliki tujuan untuk menguji dan menjelaskan bagaimana pengaruh pendapatan asli desa, dana desa, alokasi dana desa terhadap belanja desa bidang pendidikan dengan jumlah penduduk miskin sebagai variabel moderating. Jumlah sampel sebesar 12 desa yang mana peneliti mengambil 5 tahun anggaran APBDes yaitu tahun anggaran 2015-2019, dan peneliti menggunakan metode pengambilan sampel non purposive sampling. Variabel yang digunakan peneliti yaitu pendapatan asli desa, dana desa, alokasi dana desa sebagai variabel independen, belanja desa bidang pendidikan sebagai variabel dependen, dan jumlah penduduk miskin sebagai variabel moderasi. Hasil analisis yang dilakukan oleh peneliti yang dilakukan menggunakan spss menghasilkan secara silmutan pendapatan asli desa, dana desa, alokasi dana desa berpengaruh signifikan terhadap belanja desa bidang pendidikan, secara parsial pendapatan asli desa serta alokasi dana desa berpengaruh tidak signifikan terhadap belanja desa bidang pendidikan, sedangkan dana desa mempunyai pengaruh signifikan terhadap belanja desa bidang pendidikan dan jumlah penduduk memperkuat pengaruh pendapatan asli desa, dana desa, alokasi dana desa terhadap belanja desa bidang pendidikan.
\end{abstract}

Kata kunci-Pendapatan Asli Desa, Dana Desa, Alokasi Dana Desa, Belanja Desa Bidang Pendidikan, Jumlah Penduduk Miskin

ABSTRACT
This study aims to examine and explain how the influence of village income, village funds, allocation of village funds to village spending in education with the number of poor people as a moderating variable. The number of samples was 12 villages where the researchers took 5 years of the APBDes budget, namely the 2015-2019 fiscal year, and the researchers used a non-purposive sampling method. The variables used by researchers are original village income, village funds, allocation of village funds as an independent variable, village expenditure in education as the dependent variable, and the number of poor people as a moderating variable. The results of the analysis conducted by researchers conducted using SPSS silmutan produce village original income, village funds, allocation of village funds significantly influence village spending in education, partially original village income and allocation of village funds have no significant effect on education spending in the village field, while village funds have a significant influence on village expenditure in education and the population strengthens the influence of village original income, village funds, allocation of village funds to education spending in the field of education.

Keywords - Village Income, Village Fund, Village Fund Allocation, Village Expenditure in Education Sector, Number of Poor Population 


\section{PENDAHULUAN}

Indonesia saat ini terbagi atas beberapa otonomi darah, pembagian otonomi ini dilakukan pemerintah agar tercapainya tujuan pemeritah dalam penyelenggarakan otonomi ini dalam meningkatkan kesejahteraan masyarakatnya, pelayanan publiknya, dan yang terakhir untuk kemajuan ekonomi didaerah tersebut. Tata pemerintahanya Negara Kesatuan Republik Indonesia unit terkecil dalam suatu otonomi adalah desa. SDM yang berkompeten sangat dibutuhkan. Desa memiliki pendapatan desa yang cukup banyak mulai dari Pendapatan Asli Desa, Pendapatan Transfer, dan Pendapatan Lain. Pendapatan Transfer bisa didapat dari Dana Desa, Alokasi Dana Desa, dan Bagi Hasil Pajak dan Retribusi.

Fenomena yang mengenai pendidikan desa yang saat ini sering terjadi seperti yang telah diungkapkan oleh Bapak Hanafi selaku bagian pendamping anggaran DD, ADD Kecamatan Binangun kabupaten Blitar yang didapat peneliti dari hasil wawancara bahwa untuk saat ini bidang pendidikan kurang mengalami perhatian. Desa hanya menganggarkan mengenai perbaikan sarana dan prasarana dan membayar insetif gurunya padahal masih banyak warga yang belum bisa mengenyam pendidikan TK, PAUD karena keterbatasan dana. Desa juga jarang melakukan pelatihan kerja padahal ada banyak masyarakat yang menganggur. Padahal dasar desa itu memutus mata rantai kemiskinan seharusnya pemerintah desa lebih inisiatif dalam perbaikan kemiskinan desa. Seperti yang telah ditulis dalam Peraturan Menteri Desa No. 16 Tahun 2018 bahwa pemerintah memiliki beberapa pengelolaan sosial dasar yang harus dipenuhi, sosial dasar itu berupa pelayanan pada sub bidang pendidikan, sub bidang kesehatan, sub bidang pemberdayaan perempuan dan anak, serta sub bidang pemberdayaan masyarakat marginal dan anggota penyandang disabilitas. Pendamping anggaran DD, ADD merupakan intitusi yang dibentuk oleh bupati yang bertugas memberikan pendampingan pada tingkat kecamatan dan pelaksanaanya pada tingkat desa, dalam rangka mendukung keberasilan pengalokasian DD, ADD. Diberitakan pula dalam Pojoksatu.id, Hanif Dhakiri selaku Menteri Tenaga Kerja mengatakan "Dulu bila masuk BLK (Balai Latihan Kerja) harus lulusan SMA, sekarang bebas. Siapa saja tanpa memandang pendidikan formal bisa masuk. Kedua, dulu terdapat syarat umur tertentu jika masuk BLK, sekarang siapapun bisa bisa ikut pelatihan kerja. Ini tentu membantu anggatan kerja, di mana 68 persen masih didominasi lulusan SD atau SMP" dengan kata lain masyarakat yang berada diusia produktif bisa ikut serta dalam pelatihan kerja. Pelatihan kerja dari pemerintah pusat, daerah maupun desa karena masyarakat yang ikut serta dalam platihan kerja bisa meningkatkan ketrampilan dan pendidikan yang lebih baik. Desa pun sudah bisa melakukan pelatihan kerja tetapi untuk kecamatan Binangun ini masih beberapa desa saja yang menerapkan padahal kenyataanya jumlah masyarakat usia produktif kerja yang masih menganggur lumayan banyak bisa dilihat dari data BDT yang ada.

Penelitian ini juga dilatar belakangi oleh penelitian yang sebelumnya dilakukan oleh peneliti sebelumnya yang memiliki hasil penelitian yang banyak terdapat perbedaan. Penelitian yang sebelumnya dilakukan oleh Alya dkk (2018), menyatakan bahwa Pendapatan Asli Desa, Alokasi Dana Desa, dan Dana Desa berpengaruh terhadap belanja desa. Sedangkan dalam penelitian yang dilakukan oleh Amna dkk (2019) menyatakan bahwa Pendapatan Asli Desa tidak berpengaruh terhadap belanja desa sedangkan Alokasi Dana Desa berpengaruh terhadap belanja desa. Purbasari dkk (2018) menyatakan bahwa PADes memiliki pengaruh positif sedangkan DD tidak berpengaruh terhadap belanja desa, tetapi ADD berpengaruh positif terhadap belanja desa. Dewi dkk (2018) menyatakan bahwa ADD dan DD tidak berpengaruh signifikan terhadap pengalokasian belanja desa bidang pendidikan. Putra (2015) menyatakan bahwa jumlah penduduk miskin berpengaruh terhadap belanja modal. Penelitian ini bertolah belakang dengan penelitian yang dilakukan oleh Dewi dkk (2018) memiliki hasil penelitian yang hasilnya bahwa jumlah penduduk miskin berpengaruh negatif terhadap belanja desa. Berdasarkan gap dan fenomena tersebut maka peneliti mengambil judul Pengaruh Pendapatan Asli Desa (PADes), 
Sitiana Muslikah, Pengaruh Pendapatan Asli Desa (PAD), Dana Desa (DD), Alokasi Dana Desa (ADD)

Terhadap Belanja Desa Bidang Pendidikan Dengan Jumlah Penduduk Miskin Sebagai Variabel Moderasi

Dana Desa (DD), Alokasi Dana Desa (ADD) terhadap belanja desa bidang pendidikan dengan jumlah penduduk miskin sebagai variabel moderasi.

Berdasarkan hasil dari beberapa penelitian yang dilakukan peneliti maka dapat disimpulkan bahwa tidak adanya konsistenan pada penelitian yang dilakukan tersebut, sehingga penelitian yang dilakukan peneliti saat ini bermaksud meneliti ulang dengan menambahkan variabel independen serta variabel moderasi, yaitu Pendapatan Asli Desa dan Jumlah Penduduk Miskin, dalam penelitian kali ini peneliti akan melakukan pengujian kembali masalah atau persoalan yang berpaku pada penelitian terdahulu, maka peneliti mengambil judul : "Pengaruh Pendapatan Asli Desa, Dana Desa, Aokasi Dana Desa terhadap Belanja Desa Bidang Pendidikan dengan Jumlah Penduduk Miskin sebagai Variabel Moderasi"

\section{METODE PENELITIAN}

Jenis penelitian yang dilakukan peneliti kali ini bersifat kuantitatif subjek dari penelitian ini adalah desa-desa di Kecamatan Binangun dan untuk objek nya adalah PAD, DD, ADD, Jumlah Penduduk Miskin dan Belanja Desa Bidang Pendidikan yang semua itu terdapat dalam laporan APBDes setiap desa. Peneliti menggunakan data sekunder yang mana data penelitian didapat dari kantor Kecamatan Binangun. Data sekunder yang diperlukan antara lain PAD, DD, ADD Belanja Desa terutama Bidang Pendidikanya dan jumlah penduduk miskin. Populasi yang diambil oleh peneliti adalah 12 desa yang terdapat di Kecamatan Binangun. Sedangkan sampelnya yang digunakan peneliti berupa PADes, DD, dan ADD desa di Kecamatan Binangun Kabupaten Blitar tahun 2019-2015 yang berjumlah 12 desa.

\section{DEFINISI OPERASIONAL DAN PENGUKURAN VARIABEL}

Variabel yang akan diteliti dalam penelitian ini adalah Pendapatan Asli Desa, Dana Desa, Alokasi Dana Desa, Dana Desa, Belanja Desa Bidang Pendidikan, Jumlah Penduduk Miskin. Sedangkan Definisi Oprasionalnya adalah sebagai berikut :

Pendapatan Asli Desa

Pendapatan yang diperoleh melalui hasil dari usaha yang dilakukan oleh aparatur desa yang labanya digunakan untuk pemberdayaan masyarakat. Menurut Permendagri No. 20 Tahun 2018, PADesa yaitu berupa hasil usaha desa, hasil aset, hasil swadaya, partisipasi dan gotong royong, dan pendapatan asli desa lain.

Dana Desa

Dana Desa merupakan dana yang didapat dari pengalokasian dana yang didapat dari pemerintah pusat sebagai salah satu program yang terdapat dalam APBN. Menurut UndangUndang Nomer 6 Tahun 2014 Dana Desa yang didapat oleh desa senilai 10\% dari dana luar dana transfer daerah (ontop) secara bertahap, anggaran yang bersumber dari APBN jumlah dialokasikan dana desa pemerintah daerah memperhatikan jumlah penduduk, angka kemiskinan, luas wilayah, dan tingkat kesulitan geografis guna meningkatkan kesejahteraan dan pemerataan pembangunan desa.

Alokasi Dana Desa

Alokasi Dana Desa merupakan pengalokasian dana desa yang didapat dari pemerintah kabupaten/kota sebagai salah satu progam dalam APBD nya. Bedasarkan Peraturan Bupati Blitar Nomer 08 Tahun 2016 Alokasi Dana Desa yang diterima oleh masing masing desa adalah senilai $60 \%$ dibagi untuk seluruh desa, dan $40 \%$ dibagi secara proposional yang didapat dari ADD yang telah diprogamkan untuk desa-desa dikabupaten Blitar.

\section{Belanja Desa Bidang Pendidikan}

Belanja desa bidang pendidikan merupakan semua biaya yang dikeluarkan oleh desa atas dasar pengelolaan desa dibidang pendidikan yang tujuan utamanya untuk mencapai pemberdayaan masyarakat. Berdasarkan Pemendegri No. 20 tahun 2018 tentang pengelolaan 
Sitiana Muslikah, Pengaruh Pendapatan Asli Desa (PAD), Dana Desa (DD), Alokasi Dana Desa (ADD)

Terhadap Belanja Desa Bidang Pendidikan Dengan Jumlah Penduduk Miskin Sebagai Variabel Moderasi

keuangan desa, belanja desa merupakan semua pengeluaran yang merupakan kewajiban desa dalam 1 (satu) tahun anggaran yang tidak akan diterima kembali oleh desa.

Jumlah Penduduk Miskin

Jumlah penduduk miskin adalah banyaknya masyarakat yang masih belum bisa memenuhi kebutuhan ekonominya. Garis kemiskinan merupakan total dari Garis Kemiskinan Makanan (GKM) dan Garis Kemiskinan Non Makanan (GKNM). Menurut Basis Data Terpadu (BDT) merupakan data yang digunakan pemerintah untuk perencangan kegiatan/program penanggulangan kemiskinan. Pemerintah pusat,daerah maupun desa berkerja sama dengan BPS dalam menentukan warga mana yang masuk dalam katogori miskin yang selanjutnya masuk dalam data BDT.

\section{TEKNIK ANALISIS DATA}

Penelitian ini menggunakan teknik analisis data regresi berganda. Analisis ini digunakan peneliti untuk mengetahui bagaimana pengaruh dari PAD, DD, ADD terhadap Belanja Desa Bidang Pendidikan dengan Jumlah Penduduk Miskin sebagai variabel moderating. Analisis Asumsi klasik juga digunakan untuk penentuan hipotesis. Analisis yang dilakukan pada penelitian ini peneliti menggunakan progam statistik dengan bantuan aplikasi IBM SPSS 22 for windows. Yang dinyatakan dengan persamaan sebagai berikut:

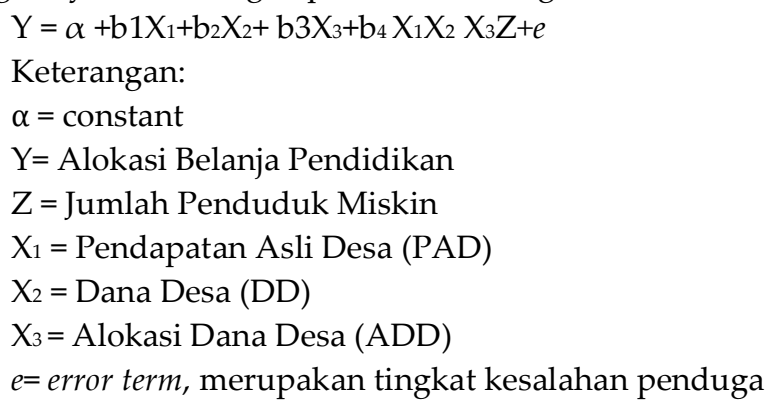

Peneliti menggunakan pengujian regresi berganda jadi seharusnya peneliti perlu melakukan pengujian asumsi klasik. Asumsi klasik merupakan pengujian yang digunakan untuk mengetahui apakah model regresi tersebut apakah bisa digunakan untuk menguji penelitian ketahap pengujian regresi berganda. Penelitian ini mengacu pada penelitian menurut Ghozali (2018). Menurut Ghozali (2018), uji normalitas merupakan pengujian yang digunakan peneliti untuk mengetahui apakah data variabel dependen dan independen yang digunakan berdistribusi normal atau tidak. Uji multikolinearitas Menurut Ghozali (2018) merupakan pengujian yang dilakukan peneliti untuk mengetahui apakah terdapat penyimpangan yang kuat atau hubungan yang kuat antara data yang ada pada variabel independen dalam analisis persamaan regresi. Uji heteroskedasi menurut Ghozali (2018) bertujuan untuk menguji apakah dalam pengujian regresi data memiliki ketidaksamaan varian dari residu suatu antara lain. Sedangkan menurut Ghozali (2018) uji autokorelasi digunakan untuk mengetahui apakah penelitian yang dilakukan peneliti terdapat masalah atau kesalahan pengganggu pada periode sebelumnya dengan perode yang diteliti peneliti.

Setelah data diketahui apakah memenugi 4 uji sebelumnya maka data bisa diuji hipotesisnya. Pengujian Hipotesis dilakukan dengan 3 cara yaitu Pengujian Silmutan(Uji F), Pengujian Parsial(Uji Statistik $t$ ) dan Pengujian Koefisian Determinasi $\left(R^{2}\right)$. Uji $F$ atau Uji Signifikan Silmutan merupakan pengujian regresi berganda yang dilakukan peneliti untuk menguji atau untuk mengetahui apakah terdapat pengaruh yang secara serentak antara variabel independen terhadap variabel dependen dan juga peneliti menggunakan uji $\mathrm{F}$ ini untuk menganalisis secara regresi untuk variabel moderasinya. Tujuan dilakukanya uji t atau uji parsial merupakan pengujian yang dilakukan oleh peneliti untuk menguji apakah variabel independen 
Sitiana Muslikah, Pengaruh Pendapatan Asli Desa (PAD), Dana Desa (DD), Alokasi Dana Desa (ADD) Terhadap Belanja Desa Bidang Pendidikan Dengan Jumlah Penduduk Miskin Sebagai Variabel Moderasi memiliki pengaruh secara individu pervariabel terhadap variabel dependen. Pengujian hipotesis ini dilakukan untuk mengetahui apakah hipotesis memiliki tingkat kepercayaan 0,05 (5\%) atau apakah hipotesis bisa meyakinkan 0,95 . Koefisien determinasi $\left(R^{2}\right)$ merupakan pengujian yang dilakukan peneliti untuk mengetahui apakah model regresi yang digunakan bisa memaparkan variasi dari variabel dependen yang terdapat dalam penelitian.

\section{HASIL DAN PEMBAHASAN}

Uji Asumsi Klasik

\begin{tabular}{|l|l|l|}
\hline Variabel & Nilai VIF & Sig. (2-tailed) \\
\hline PADes & 1,018 & 0,90 \\
\hline DD & 2,155 & 0,888 \\
\hline ADD & 2,158 & 0,786 \\
\hline Asymp. Sig. (2-tailed) : 0,200 & \\
\hline Durbin-Watson 1,590 \\
\hline
\end{tabular}

Dari hasil spss yang dilakukan peneliti menghasil kan nilai Asymp.Sig. (2-tailed) senilai $0,200>0,05$ yang berati data berdistribusi normal. Nilai VIF yang di dapat pervariabel $>10$ sehingga data tidak terjadi multikolinieritas. Nilai Sig. (2-tailed) juga $>0,05$ yang berarti data tidak terjadi heteroskedasitas. Hasil SPSS tersebut juga menghasilkan nilai Durbin-Watson sebesar 1,590 yaitu nilai tersebut berada di antara 1.48-1.69, hasil tersebut dapat diartikan bahwa model regresi yang dilakukan peneliti tidak terjadi autokorelasi.

\section{Hasil Analisis Regresi Liniar Berganda}

Hasil analisis pada model regresi moderasian bisa diuat pesamaan regresi sebagaimana dibawah ini:

$\mathrm{Y}=\alpha+\mathrm{b} 1 \mathrm{X}_{1}+\mathrm{b}_{2} \mathrm{X}_{2}+\mathrm{b} 3 \mathrm{X}_{3}+\mathrm{b}_{4} \mathrm{X}_{1} \mathrm{X}_{2} \mathrm{X}_{3} \mathrm{Z}+e$

$\mathrm{Y}=72,353+0,365 \mathrm{X}_{1}+1,185 \mathrm{X}_{2}-4,232 \mathrm{X}_{3}+0,000 \mathrm{X}_{1} \mathrm{X}_{2} \mathrm{X}_{3} \mathrm{Z}+e$

\begin{tabular}{|l|l|l|l|}
\hline Variabel & $\mathbf{B}$ & Sig uji t & Kesimpulan \\
\hline $\mathbf{X}_{1} \mathbf{X}_{2} \mathbf{X}_{3}$ & & 0,020 & Signifikan \\
\hline $\mathbf{X}$ (PAD) &, 365 &, 091 & Tidak signifikan \\
\hline $\mathbf{X}$ (DD) & 1,185 &, 015 & Signifikan \\
\hline $\mathbf{X} 3$ (ADD) & $-4,238$ &, 437 & Tidak signifikan \\
\hline $\mathbf{X}_{1} \mathbf{X}_{2} \mathbf{X}_{3} Z$ & 0,000 & Signifikan \\
\hline Konstanta: 72,353 & 0,000 \\
\hline Nilai Signifikan uji F: 0,483 & \\
\hline F: 3,556 & \\
\hline Nilai R-Square: $\mathbf{0 , 1 6 0}$ & \\
\hline Nilai R-Square setelah moderasi: $\mathbf{0 . 1 9 8}$ & \\
\hline
\end{tabular}

Berdasarkan hasil persamaan regresi sebagaimana tersebut bisa ditarik kesimpulan bahwa. Konstanta sebesar 72,353 memiliki arti jika variabel Pendapatan Asli Desa (X1), Dana Desa (X2), Alokasi Dana Desa (X3) = 0 (tidak ada biaya Pendapatan Asli Desa, Dana Desa, dan Alokasi Dana Desa), maka Belanja Desa Bidang Pendidikan (Y) yang dicapai adalah sebesar 72,353 (dalam jutaan rupiah). Pendapatan Asli Desa memiliki pengaruh positif (searah) artinya peningkatan Pendapatan Asli Desa 1 satuan ( 1 juta) akan menyebabkan peningkatan Belanja Desa Bidang Pendidikan sebesar 0,365 satuan (0,365 juta). Dana Desa memiliki pengaruh positif (searah) artinya peningkatan Dana Desa 1 satuan (1 juta) akan menyebabkan peningkatan Belanja Desa Bidang Pendidikan sebesar 1,185 satuan (1,185 juta) atau sebaliknya. Alokasi Dana Desa memiliki pengaruh negatif (menurun) artinya peningkatan Alokasi Dana Desa 1 satuan (1 juta) akan 
Sitiana Muslikah, Pengaruh Pendapatan Asli Desa (PAD), Dana Desa (DD), Alokasi Dana Desa (ADD)

Terhadap Belanja Desa Bidang Pendidikan Dengan Jumlah Penduduk Miskin Sebagai Variabel Moderasi

menyebabkan penurunan Belanja Desa Bidang Pendidikan sebesar 4,238 satuan (4,238 juta) atau sebaliknya.

Koefisien regresi (beta= $=$ ) yang sudah di standarisasi atas variabel moderasi (X1X3X3) bertanda positif 0.000 . Hasil tersebut dapat ditarik kesimpulan bahwa variabel moderasi (jumlah penduduk miskin) berhubungan positif dengan variabel belanja desa bidang pendidikan. Hal tersebut memiliki arti bahwa, apabila nilai variabel X1X2X3 dinaikkan satuan, maka jumlah nilai variabel belanja desa bidang pendidikan akan naik 0.000 satuan. Berdasarkan dugaan pada variabel yang lain tidak berubah. Nilai $R$-square 0.160 , nilai $R$-square dapat menghasilkan analisis yang memiliki arti bahwa variabel Belanja Desa Bidang Pendidikan 16.0 persen dipengaruhi oleh variabel pendapatan asli desa, dana desa, alokasi dana desa. Hasil stersebut selanjutnya dikurangkan senilai $10 \%$ yang menghasilkan sebesar 84.0 persen yang berarti variabel dependen dipengaruhi oleh variabel lain yang tidak diteliti seperti begi hasil pajak dan retribusi dan pendapatan lain yang diterima oleh desa. Peneliti tidak meniliti variabel tersebut karena peneliti memfokuskan pada hasil penelitian terdahulu yang kurang konsisten mengenai variabel yang mempengaruhi pendapatan asli desa, dana desa, dan alokasi dana desa

\section{HASIL UJI HIPOTESIS}

\section{Hasil Uji Hipotesis Pertama}

Hasil uji signifikasi silmutan menunjukkan bahwa signifikansi f lebih kecil dari significiance level, yaitu 0,020<0,05 atau alpa 5\%. Hasil analisis SPSS tersebut dapat dikemukakan bahwa Ha. 1 diterima (didukung oleh data).

\section{Hasil Uji Hipotesis Kedua}

Hipotesis kedua Ha.2, hasil signifikansi uji t atas variabel Pendapatan Asli Desa (X1) yakni sebesar 0,091 lebih besar dari alpha 0,05 (5\%). Hasil Analisis tersebut dapat diartikan bahwa Ha.2 memiliki arti bahwa Pendapatan Asli Desa berpengaruh secara positif ditolak (tidak didukung oleh data).

\section{Hasil Uji Hipotesis Ketiga}

Hipotesis ketiga Ha.3, hasil signifikansi uji $t$ atas variabel Dana Desa (X2) yakni senilai 0,015 lebih kecil dari alpha 0,05 (5\%). Hasil Analisis tersebut dapat diartikan bahwa Ha.2 yang memiliki makna bahwa Pendapatan Asli Desa berpengaruh secara positif diterima (didukung oleh data).

\section{Hasil Uji Hipotesis Keempat}

Hipotesis keemat Ha.4, hasil signifikansi uji t atas variabel Alokasi Dana Desa (X3) yakni senilai 0,437 lebih besar dari alpha 0,05 (5\%). Hasil Analisis tersebut dapat diartikan bahwa Ha.2 yang memiliki makna bahwa Pendapatan Asli Desa berpengaruh secara negatif ditolak (tidak didukung oleh data).

\section{Hasil Uji Hipotesis Kelima}

Hasil analisis SPSS menunjukkan sebelum dimoderasi memiliki nilai $R$-Square 0,160 dan setelah dimoderenisasi memiliki $R$-Square 0,198 yang berarti terdapat peningkatan $R$-Square sehingga dapat dikemukakan bahwa jumlah penduduk miskin sebagai variabel moderasi bisa memperkuat. Berdasarkan data setelah dilakukan moderasi nilai sig adalah 0,032 $<0,05$ sehingga data signifikan sehingga data berpengaruh. Hasil analisis tersebut dapat diartikan bahwa, hipotesis keempat yang memiliki makna bahwa jumlah penduduk miskin memperkuat pengaruh pendapatan asli desa, dana desa, alokasi dana desa terhadap belanja desa bidang pendidikan diterima. 
Sitiana Muslikah, Pengaruh Pendapatan Asli Desa (PAD), Dana Desa (DD), Alokasi Dana Desa (ADD)

Terhadap Belanja Desa Bidang Pendidikan Dengan Jumlah Penduduk Miskin Sebagai Variabel Moderasi

\section{PEMBAHASAN}

Pengaruh pendapatan asli desa, dana desa, alokasi dana desa secara silmutan terhadap belanja desa bidang pendidikan

Hasil pengujian dapat membuktikan terdapat pengaruh secara silmutan antara pendapatan asli desa, dana desa, alokasi dana desa terhadap belanja desa bidang pendidikan. Hasil tersebut menunjukkan bahwa ada signifikan secara silmutan antara pendapatan asli desa, dana desa, alokasi dana desa terhadap belanja desa bidang pendidikan. Seperti yang telah dikemukakan oleh Alya dkk (2018) bahwa dalam pembangunan desa, desa mempunyai wewenang dalam mengelola semua pendapatan yang masuk ke desa bisa digunakan untuk membiayai belanja yang dilakukan desa untuk kebutuhan masyarakatnya yang mana pendapatan desa diantaranya terdiri dari Pendapatan Asli Desa, Dana Desa, dan Alokasi Dana Perimbangan Desa. Bidang pendidikan merupakan salah satu bagian dari bidang pembangunan. Bidang pembangunan desa sendiri terdiri dari sub bidang pendidikan, kesehatan, pekerjaan umum, dan lain-lain. Pembangunan desa tidak selalu berupa pembangunan berupa fisik saja tetapi pembangunan non fisik seperti pengambangan dan pembinaan bak masyarakat maupun pemerintah desanya agar masyarakat desa lebih sejahtera. Pembangunan fisik maupun non fisik sangat dibutuhkan bagi masyarakat karena masyarakat saat ini sangat membutuhkan fasilitas fisik maupun non fisik dalam melakukan kegiatan yang ada agar desapun bisa bersaing dengan desa lain maupun daerah kota. Desa saat ini diharapkan lebih kreatif serta inovatif dalam pengelolaan keuangan desa yang ada karena jumlah dana yang diterima karena dana yang didapatkan oleh desa pun lumayan besar, jika pemerintah desa bisa mengelolanya dengan baik dan maksimal maka desa bisa lebih maju. Pendapatan yang banyak ini merupakan langkah inovasi atau perbaikan dari pemerintah pusat dalam membangun negeri. Pemerintah pusat merasa tidak bisa maksimal dalam pemerataan realisasi dana dari hasil pendapatan yang diterima negara. Hal ini serupa dengan penelitian dari Sumiyati (2018) yang mana Pendapatan Asli Desa, Dana Desa, Bagi Hasil Pajak dan Retribusi berpengaruh secara silmutan terhadap belanja desa.

\section{Pengaruh pendapatan asli desa terhadap belanja desa bidang pendidikan}

Hasil pengujian tidak membuktikan terdapat pengaruh pendapatan asli desa terhadap belanja desa bidang pendidikan. Hasil pengujian yang dilakukan menggunakan aplikasi SPSS dari data yang telah dipaparkan tersebut maka menghasilkan kesimpulan bahwa terdapat pengaruh yang positif tetapi tidak signifikan antara pendapatan asli desa terhadap belanja desa bidang pendidikan. Hasil penelitian yang telah dipaparkan pada tabel sebelumnya dapat dikemukakan bahwa hipotesis yang telah dipaparkan pada sub bab sebelumnya tidak bisa diterima karena dari hasil pengujian SPSS pendapatan asli desa tidak mempunyai pengaruh terhadap belanja desa bidang pendidikan. Jumlah pendapatan yang minin yang didapat oleh desa dengan adanya regulasi baru yaitu Peraturan Menteri Desa No. 16 tahun 2018 yang mana dana desa saat ini memiliki prioritas untuk kegiatan pembangunan desa serta pemberdayaan desa. Pendapatan ini selaras dengan penelitian yang di lakukan oleh Amnam dkk (2019) yang mana jumlah pendapatan yang kecil dapat mempengaruhi nilai belanja yang digunakan dalam pendapatan asli desa. Berdasarkan Undang-Undang No. 06 Tahun 2014 bahwa pemerintah desa untuk saat ini dituntut untuk lebih mandiri lagi dalam proses mengatur serta mengurus semua kebutuhan desa yang dianggap penting, pemerintah desa tidak boleh hanya tergantung akan dana yang berasal dari pemerintah pusat maupun daerah desa harus bisa medapatkan pendapatan sendiri baik dari hasil usaha, hasil sewa, swadaya, partisipasi ataupun dari gotong royong. Pendapatan asli desa bisa menjadi pendapatan tambahan pendapatan bagi pemerintah desa dalam proses pembangunan desa. Pendapatan asli desa merupakan salah satu sumber pendapatan yang diperoleh oleh desa itu sendiri, PADes ini diharapkan bisa menjadi pendapatan 
Sitiana Muslikah, Pengaruh Pendapatan Asli Desa (PAD), Dana Desa (DD), Alokasi Dana Desa (ADD)

Terhadap Belanja Desa Bidang Pendidikan Dengan Jumlah Penduduk Miskin Sebagai Variabel Moderasi

yang bisa diandalkan oleh pemerintah desa. Pendapatan asli desa ini diharapkan untuk bisa menompang pembangunan yang ada di desa sehingga masyarakat desa menjadi masyarakat yang sejahtera. Penelitian ini juga didukung dengan penelitian yang pernah dilakukan oleh Alya dkk (2018) yang menghasilkan hasil uji bahwa Pendapatan Asli Desa .berpengaruh positif terhadap belanja desa. Hal ini ditolak oleh Amnan dkk (2019) yang menyatakan bahwa Pendapatan Asli Desa (PAD) tidak berpengaruh dan negatif signifikan terhadap belanja desa.

\section{Pengaruh dana desa terhadap belanja desa bidang pendidikan}

Dari hasil pengujian membuktikan terdapat pengaruh dana desa terhadap belanja desa bidang pendidikan. Peraturan Menteri Desa No. 16 Tahun 2018 menyatakan bahwa dana desa ini memiliki prioritas utama yaitu untuk membiayai progam serta kegiatan pada bidang pembangunan desa dan pemberdayaan desa. Pendidikan merupakan bagian dari pemberdayaan masyarakat sehingga pemerintah desa lebih memrioritaskan dana desa ini sebagai pembiayaan bidang pendidikan baik itu untuk pembangunan maupun pembayaran insetif pendidik. Dijadikanya dana desa sebagai prioritas diharapkan bisa menghasilkan manfaat semaksimal mungkin bagi warga masyarakat desa sehingga masyarakat mengalami peningkatan pada kualitas hidupnya, dan semakin sejahtera kehidupanya sehingga asyarakat miskin semain berkurang insfrakturktur di desa pun semakin baik lagi sehingga pelayanan desa pun semakin mewadai. Dana desa merupakan dana yang paling tinggi dari pada pendapatan lain yang diperoleh desa. Keadaan ini memungkinkan pemerintah desa lebih menggunakan dana desa sebagai salah satu dari pendapatan desa yang masuk ke desa dan paling berpengaruh, karena saat ini desa lebih berfokus pada peningkatan insfrastruktur baik itu bidang pendidikan ataupun yang lain. Pemerintah desa saat ini kurang maksimal dalam pengelolaan belanja desanya di mana mereka hanya berfokus pada insfrastrukturnya sedangkan saat ini desa bisa maju danberkembang bisa melalui pelatihan kerja. Hasil pengolahan data menggunakan SPSS yang dilakukan peneliti bahwa hipotesis ketiga dapat diterima yang menduga bahwa dana desa mempunyai pengaruh terhadap belanja desa bidang pendidikan. Penelitian ini juga didukung penlitian yang oleh Amiyati \& Dwi (2018) yang menghasilkan kesimpulan bahwa Dana Desa tidak berpengaruh terhadap belanja desa bidang pendidikan. Hasil tersebut tidak selaras dengan penelitian yang dilakukan oleh Alya dkk (2018) yang menghasilkan kesimpulan bahwa Dana Desa memiliki pengaruh positif signifikan terhadap belanja desa. Tetapi penelitian ini juga diperkuat dengan penelitian yang dilakukan oleh Sumiyati (2018) yang menghasilkan kesimpulan bahwa Dana Desa berpengaruh signifikan terhadap belanja desa.

\section{Pengaruh alokasi dana desa terhadap belanja desa bidang pendidikan}

Hasil pengujian tidak membuktikan terdapat pengaruh alokasi dana desa terhadap belanja desa bidang pendidikan. Hasil tersebut menunjukkan bahwa ada pengaruh negatif dan tidak signifikan alokasi dana desa terhadap belanja desa bidang pendidikan. Hasil penelitian dapat disimpulkan hipotesis keempat tidak dapat diterima yang menduga bahwa alokasi dana desa tidak mempunyai pengaruh terhadap belanja desa bidang pendidikan. Berdasarkan UdangUndang No. 06 Tahun 2014 bahwa penghasilan tetap kepala desa serta perangkat desa bisa diambilkan dari dana yang berasal dari Anggaran Pendapatan dan Belanja Daerah dana tersebut bisa dikatakan merupakan dana yang disalurkan ke desa yang berasal dari APBD yang biasa disebut dengan ADD. Berdasarkan penjelasan tersebut, dapat dikemukakan bahwa untuk saat ini alokasi dana desa masih kurang maksimal dalam penggunaan dana nya untuk bidang pendidikan karena pemerintah desa lebih terpaku akan peraturan yang telah dikeluarkan oleh pemerintah daerah. Tetapi dalam Peraturan Bupati Blitar No. 08 Tahun 2016 besaran ADD pun seharusnya tidak hanya digunakan untuk penghasilan tetap kepala desa tetapi bisa juga digunakan dalam bidang berbagai bidang seperti bidang penyelenggaraan pemerintah desa, 
bidang pembangunan desa, bidang pemberdayaan masyarakat desa, dan yang terakhir bidang pembianaan kemasyarakatan desa. Alokasi Dana Desa seharusnya lebih bisa digunkan lebih maksimal lagi bisa digunakan tambahan untuk pelatihan kerja karena seperti yang dijelaskan sebelumnya pelatihan kerja saat ini sangat penting karena untuk meningkatkan pengetahuan dan standar masyarakat karena yang terjadi di lapangan masih banyak warga yang hanya lulusan SD-SMP padahal saat ini pendidikan minimal yang dibutuhkan adalah SMA/SMK dengan adanya pelatihan bisa menjadikan nilai lebih bagi masyarakat yang hanya mempunyai pendidikan di bawah standar bisa juga bersaing dengan masyarakat lain yang bisa membiayai pendidikan sampai SMA/SMK. Desa yang lebih berfokus pada insfrastruktur perlu melakukan inovasi lain dalam bidang-bidang yang lain terutama dalam peningkatan sumber daya manusia agar masyarakat miskin pun semakin berkurang. Pendapat selaras dengan penelitian sebelumnya yang dimana dilakukan oleh Amiyati \& Dwi (2018) yang mana Alokasi Dana Desa tidak berpengaruh terhadap belanja desa. Dewi (2018) juga melakukan pnelitian yang mana menghasilkan hasil Dana Desa tidak signifikan terhadap belanja desa. Hasil penelitian ini telah dibantah dengan penelitian yang yang dilakukan oleh Amnan et al (2019) yang menyatakan bahwa Alokasi Dana Desa berpengaruh positif signifikan terhadap belanja desa.

\section{Jumlah Penduduk Miskin Memperkuat Pengaruh Pendapatan Asli Desa, Dana Desa, Alokasi Dana Desa Terhadap Belanja Desa Bidang Pendidikan}

Dari hasil pengujian membuktikan bahwa jumlah penduduk miskin memperkuat pengaruh pendapatan asli desa, dana desa, alokasi dana desa terhadap belanja desa bidnag pendidikan. Setelah peneliti menggunakan SPSS peneliti dapat menyimpulkan bahwa jumlah penduduk miskin mampu menjadi moderasi antara pendapatan asli desa, dana desa terhadap belanja desa bidang pendidikan. Hasil R-Square yang di dapat dari hasil sebelum moderasi dan sebelum moderasi mengalami peninkatan. Hasil pengujian tersebut dengan demikian membuktikan bahwa jumlah penduduk miskin mampu memoderasi hubungan pendapatan asli desa, dana desa, alokasi dana desa terhadap belanja desa bidang pendidikan. Kesimpulan hasil analisis berarti jumlah penduduk miskin mampu memperkuat hubungan pendapatan asli desa, dana desa, alokasi dana desa terhadap belanja desa bidang pendidikan. Berdasarkan penelitian terdahulu dari Sari \& Novi (2018) yang mana memiliki pernyataan bahwa dengan adanya pendapatan desa yang masuk diharapkan pemerintahh desa bisa menggunakan dana ini dengan sebaik-baiknya yang terutama dalam bidang pembangunan desa yang nantinya bisa berdampak terhadap penerunan tingkat kemiskinan desa. Bidang pembangunan sendiri ada beberapa sub bidang antara lain sub bidang pendidikan, sub bidang kesehatan, sub bidang pekerjaan umum dan penataan ruang, sub bidang kawasan permukiman, sub bidang kehutanan dan lingkungan hidup, sub bidang perhubungan, komunikasi, dan informatika, serta sub bidang pariwisata. Selain itu berdasakan penelitian dari Dewi (2018) yang menyatakan bahwa desa sangat memiliki peranan yang sangat penting dalam penangulangan kemiskinan karena desa merupakan unit yang paling dekat dengan masyarakat, dalam penanggulangan kemiskinan ini salah satu cara yang bisa dilakukan pemerintah desa adalah dengan meningkatkan atau memperkuat tingkat kesejahteraan masyarakat. Sebenanya semua pendapatan desa bisa digunakan untuk bidang pendidikan tetapi berdasarkan Peraturan Mentri No. 16 Tahun 2018 yang berisi bahwa dana yang menjadi prioritas dalam proses perbaikan pembangunan desa merupakan dana desa. Hal ini yang mengakibatkan pemerintah desa lebih menggunakan Dana Desa dalam pengalokasian belanja desa bidang pendidikan.

\section{KESIMPULAN}

Berdasarkan pengujian serta penjelasan yang telah dipaparkan tersebut dapat menghasilkan kesimpulan bahwa, secara silmutan pendapatan asli desa, dana desa, alokasi dana 
Sitiana Muslikah, Pengaruh Pendapatan Asli Desa (PAD), Dana Desa (DD), Alokasi Dana Desa (ADD)

Terhadap Belanja Desa Bidang Pendidikan Dengan Jumlah Penduduk Miskin Sebagai Variabel Moderasi

desa berpengaruh terhadap belanja desa bidang pendidikan. Secara parsial pendapatan asli desa dan alokasi dana desa tidak berpengaruh signifikan terhadap belanja desa bidang pendidikan, dan untuk dana desa berpengaruh secara signifikan terhadap belanja desa bidang pendidikan. Pengujian moderasi yang dilakukan peneliti membukikan bahwa jumlah penduduk miskin bisa memoderasi pendapatan asli desa, dana desa, serta alokasi dana desa terhadap belanja desa bidang pendidikan.

\section{SARAN}

Sebaiknya pemerintah desa lebih berfokus pada pengelolaan sumber daya yang dimiliki desa baik itu sumber daya alamnya maupun sumber daya manusianya sehingga tidak mengalami ketertinggalan dengan desa lain atau bisa bersaing dengan masyarakat lain. Sedangkan untuk penelitian terdahulu bisa saja menambahkan variabel BHBR sebagai variabel $\mathrm{x}$, memperluas populasi, mengganti variabel y dengan belanja modal.

\section{DAFTAR PUSTAKA}

Aditya Putra Widiagama. (2015). Pengaruh Indeks Pembangunan Manusia ( IPM ) dan Jumlah Penduduk terhadap Belanja Modal Pemerintah Daerah Kabupaten / Kota di Provinsi Jawa Timur ( Influence Human Development Index ( HDI ) and Total Population against District / City Governments ' s Capit. Artikel Ilmiah Mahasiswa, 1-5.

Alya, M., \& Dkk. (2018). Pengaruh Pendapatan Asli Desa, Dana Desa, Dan Alokasi Dana Perimbangan Desa Terhadap Belanja Desa ( Study Kasus pada Desa di Kabupaten Bandung Tahun 2017). Jurnal Aksara Public, 2(September), 160-164.

Amiyati, N., \& Dwi, A. (2018). Pengaruh Jumlah Penduduk Miskin, Alokasi Dana Desa (ADD) dan Dana Desa (DD) Terhadap Pengalokasian Belanja Pendidikan (Studi Empiris di DesaDesa Se-Kabupaten Wonogiri Tahun 2017). Seminar Nasional Dan The 5th Call For Syariah Paper (SANCALL) 2018, 91(5), 1-13. https://doi.org/10.1017/CBO9781107415324.004

Amnan, A. R., Sjahruddin, H., \& Hardiani. (2019). Pengaruh Alokasi Dana Desa dan Pendapatan Asli Desa Terhadap Belanja Desa. Jurnal Organisasi Dan Manajemen, (October). https://doi.org/10.5281/zenodo.3484027

Dewi, R., Dwi, A., \& Bawono, B. (2018). Belanja Pendidikan Dengan Alokasi Dana Desa ( ADD ) Dan Dana Desa ( DD ) Sebagai Variabel Moderating Tahun 2017 ( Studi Empiris di DesaDesa Kabupaten Wonogiri ). Jurnal Ilmiah Akuntansii, XVII(2), 180-198.

Purbasari, H., Puspawati, D., Lestari, S., Pratiwi, K., Akuntansi, P. S., Surakarta, U. M., \& Pos, T. (2018). Analisis Pendapatan Asli Desa ( PADES), Dana Desa ( DD ), Alokasi Dana Desa ( ADD ), Dan Bagi Hasil Pajak Dan Retribusi ( BHPR ) Terhadap Belanja Modal Desa Di Kabupaten Wonogiri Tahun 2017. The 8th University Research Colloquium 2018, (Proceeding of The 8th University Research Colloquium 2018: Bidang Pendidikan, Humaniora dan Agama), 487-492.

Sari, R. D., \& Novi, O. I. (2018). Pengaruh Pendapatan Asli Desa, dan Alokasi Dana Desa Terhadap Belanja Desa dan Kemiskinan. Jurnal Riset Akuntansi Multiparadigma, 2(2), 1-15.

Sarwoko, E. (2018). Analisis Statistik Menggunakan SPSS 22. Malang: Media Nusa Creative. 